\title{
Dating Prograde Amphibolite and Granulite Facies Metamorphism Using In Situ Monazite U-Pb SHRIMP Analysis
}

\author{
C. J. Forbes, ${ }^{1}$ D. Giles, ${ }^{2}$ P. G. Betts, ${ }^{2}$ R. Weinberg, and P. D. Kinny ${ }^{3}$ \\ Predictive Mineral Discovery Cooperative Research Centre, School of Geosciences, Monash University, Clayton, \\ Victoria 3800, Australia, and Australian Crustal Research Centre, School of Geosciences, \\ P.O. Box 28E, Monash University, Clayton, Victoria 3800, Australia \\ (e-mail: caroline.forbes@adelaide.edu.au)
}

\begin{abstract}
A B S T R A C T
In situ SHRIMP U-Pb analysis of monazite grains from pelites within an early-formed high-temperature shear zone in the southern Broken Hill Block, Australia, has been used to constrain the timing of prograde amphibolite facies and peak granulite facies metamorphism within the terrain. Geochronological analyses from grains inhabiting texturally distinct localities revealed two distinct age populations, ca. 1619 and $\sim 1600 \mathrm{Ma}$. The older age was obtained from grains that occur as inclusions completely enclosed within coarse-grained K-feldspar and garnet grains, which evidently armored the monazite inclusions against resetting during younger deformation and metamorphic events. The ca. 1619-Ma monazite population occurs as part of an amphibolite facies inclusion assemblage hosted within the peak granulite facies mineral assemblage and constrains the timing of prograde amphibolite facies metamorphism within the Broken Hill Block. The younger 1600-Ma monazite age population was from grains within the pervasive shear fabric of the pelites or adjacent to fractures or grain boundaries in the matrix. The $\sim 1600-\mathrm{Ma}$ age population represents either a later stage of monazite growth or isotopic resetting during deformation along the high-temperature shear zone at peak granulite facies conditions.
\end{abstract}

Online enhancement: appendix table.

\section{Introduction}

Shear zones are key structures to unraveling the evolution of a terrain because they are localized areas into which strain is partitioned during deformation and can therefore record evidence of the kinematic history of a terrain that may go unrecognized in less deformed rock packages (e.g., Goodge et al. 1993; Shaw et al. 2001). However, within complexly polydeformed terrains, evidence of early deformation within the shear zones may be subtle and may have been overprinted and obscured during subsequent deformational and metamorphic events. Placing absolute timing con-

Manuscript received April 5, 2007; accepted June 5, 2007.

${ }^{1}$ Author for correspondence. Present address: School of Earth and Environmental Sciences, University of Adelaide, Adelaide, South Australia 5005, Australia.

${ }^{2}$ Australian Crustal Research Centre, School of Geosciences, P.O. Box 28E, Monash University, Clayton, Victoria 3800, Australia.

${ }^{3}$ Institute for Geoscience Research, Curtin University of Technology, Bentley, Western Australia 6845, Australia. straints on early deformation events can also be difficult due to the possibility of multiple mineral growth events and the necessity to use an isotopic system with an appropriate closure temperature that will allow dating of events that may predate peak metamorphic conditions.

The Broken Hill Block, Australia (fig. 1), is an example of a complexly polydeformed terrain for which placing timing constraints on deformational and thermal events that occurred before peak regional low-pressure granulite facies metamorphism is difficult. Additionally, the mechanism of regional metamorphism itself is conjectural. Peak metamorphic conditions in the Broken Hill Block are closely associated with intense deformation attributed to the Olarian Orogeny at ca. 1600-1590 Ma (Page et al. 2000). However, it is not clear whether high-temperature/low-pressure metamorphism was a result of orogenic processes (e.g., Loosveld and Etheridge 1990) or was influenced by a 


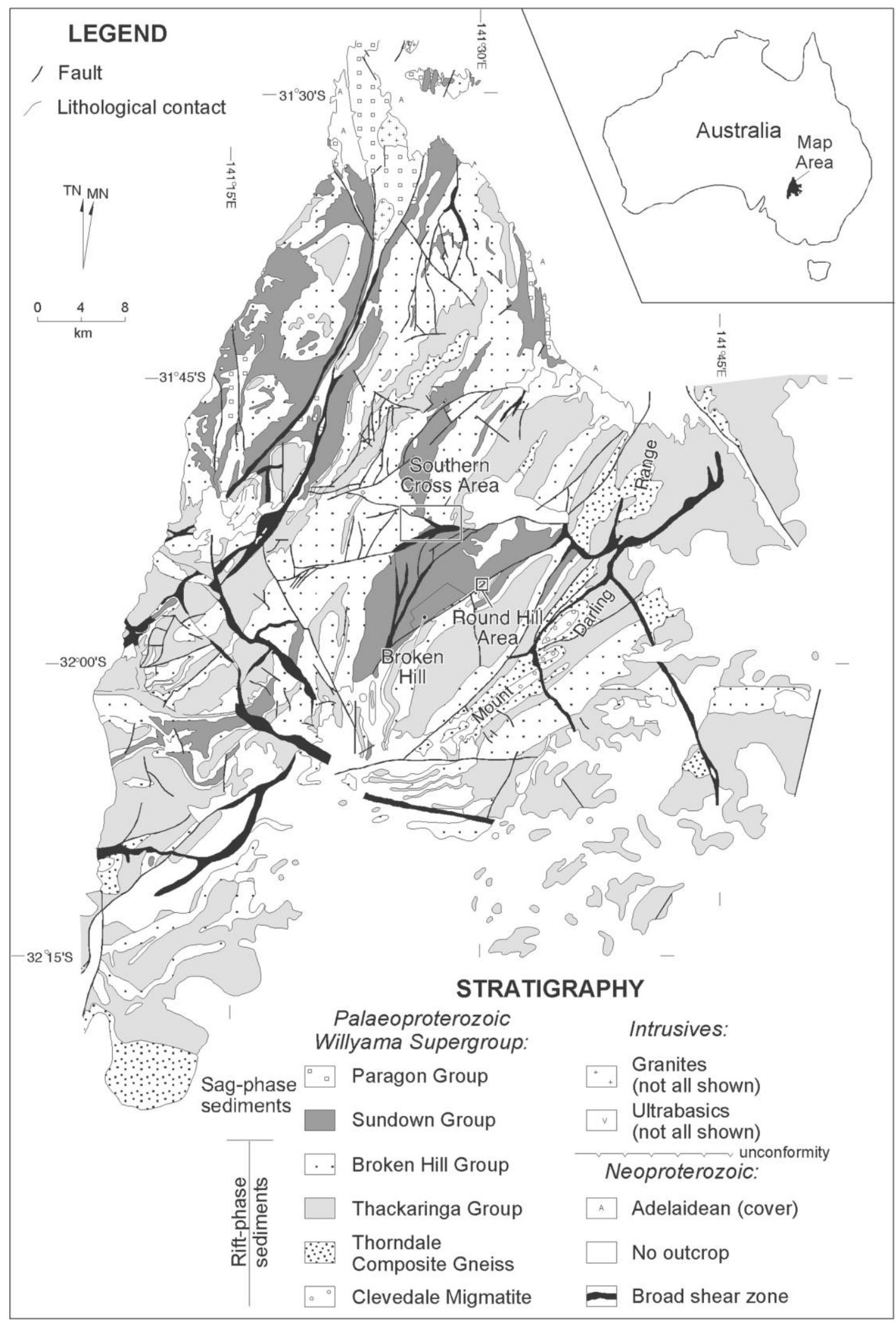

Figure 1. Geological map of the Broken Hill Block, showing major geological units and a basic stratigraphic column (adapted after Willis et al. 1983). 
preorogenic event (e.g., lithospheric thinning or redistribution of heat-producing elements). The causes of high-temperature metamorphism have long been considered in a shortening context (e.g., Hobbs et al. 1984; Loosveld and Etheridge 1990); however, with recent suggestions of an episode of extensional deformation before orogenesis, this requires reconsideration (e.g., Gibson and Nutman 2004; Gibson et al. 2004; Forbes et al. 2005). Extension is interpreted to have been accommodated along early-formed, layer-parallel high-temperature shear zones (e.g., Gibson and Nutman 2004). Additionally, a tectonothermal event before the development of these high-temperature shear zones and associated fabric has been resolved through detailed structural and metamorphic analysis of a high-temperature shear zone in the southern Broken Hill Block (Forbes et al. 2005). This event was associated with elevated geothermal gradients and is attributed to early extension. Determining the absolute timing of the early tectonothermal events, as well as the thermal regime associated with activity along the high-temperature shear zones, is crucial in establishing the early history of the Broken Hill Block and in determining whether a preorogenic event(s) may have influenced the thermal state of the crust during shortening. However, constraining the absolute timing of these events has proven difficult as the extreme conditions of later peak granulite facies metamorphism attained in the Broken Hill Block are above the closure temperatures of most mineral isotopic systems and has caused them to be reset.

The U-Pb isotopic system is considered a useful conventional geochronological isotopic system for determining the absolute timing of early tectonothermal events within the Broken Hill Block because it has a high closure temperature within some common U-bearing accessory phases (e.g., zircon [Lee et al. 1997] and monazite [Copeland et al. 1988; Parrish 1990; Cherniak et al. 2004]). Zircon SHRIMP U-Pb has been used extensively in determining depositional ages of rock packages and timing of major metamorphic and deformational events within the terrain (e.g., Page and Laing 1992; Nutman and Ehlers 1998; Page et al. 2000; Gibson and Nutman 2004), and a summary of these studies is given by Raetz et al. $(2002 b)$. However, the use of standard grain mounts in SHRIMP U-Pb geochronology, although highly effective in determining major age populations, does not retain the textural context of the grains, and subtle complexities in grain populations may be easily missed.

In this study, we apply in situ SHRIMP U-Pb monazite geochronology to samples from within and proximal to an early-formed high-temperature shear zone in the southern Broken Hill Block of the Curnamona Province, Australia (fig. 1). In situ analysis of accessory phases has allowed separation of $\mathrm{U}-\mathrm{Pb}$ age populations that reside in specific textural localities within surrounding deformational fabrics and porphyroblastic minerals that have previously been indistinguishable using conventional mineral separate geochronology. Results of this study provide constraints on the timing of activation of hightemperature shear zones and their activity in relation to the timing of peak granulite facies metamorphism within the terrain. Additionally, the use of in situ monazite dating has enabled resolution of two distinct metamorphic events in the geochronological record and construction of a prograde pressure-temperature $(P T)$ path for the Broken Hill Block.

\section{The Broken Hill Block}

The Broken Hill Block (fig. 1) comprises the polydeformed Early Proterozoic Willyama Supergroup (fig. 1; Willis et al. 1983; Stevens et al. 1988). Lower units of the Willyama Supergroup are dominated by lower quartzofeldspathic-dominated sediments grading into turbidite sequences that were deposited within an evolving rift basin (e.g., Stevens et al. 1988) at ca. 1710-1670 Ma (Page et al. 2000, 2005; fig. 1). Felsic and mafic volcanic rocks occur throughout the rift sequences. These are overlain by a succession of pelites, psammites, calc-silicate rocks, and graphitic phyllites and schists deposited during the postrifting evolution of the basin (Willis et al. 1983; Stevens et al. 1988; Walters 1996; fig. 1). Sag-phase sediments were deposited between 1660 and $1600 \mathrm{Ma}$ (Page et al. 2000, 2005; Raetz et al. $2002 b$ ).

Recently, Gibson and Nutman (2004) placed the Broken Hill Block in the context of a metamorphic core complex at ca. 1690-1670 Ma, during the time of deposition of the Willyama Supergroup. Regionally extensive, layer-parallel high-temperature shear zones were suggested to have accommodated extension and were associated with the development of a regionally pervasive high-temperature, layer-parallel fabric. Other workers have also described the formation of early high-temperature shear zones that are interpreted to be extensional (e.g., Noble and Lister 2001; Venn 2001); however, consensus on the timing of development of these shear zones has not been reached. Venn (2001) postulated high-temperature shear zone development just before intense crustal shortening during the Olarian Orogeny (ca. 1600-1590 Ma; Page et al. 
2000), while Gibson and Nutman (2004) advocated shear zone development at ca. 1690-1670 Ma. Interpretations of a midcrustal extensional phase within the Broken Hill Block have been surrounded by controversy because unequivocal demonstration of an extensional origin for high-temperature shear zone development has been difficult. This is due to the fact that the structures were intensely folded and reactivated during the Olarian (ca. 1600-1590 $\mathrm{Ma}$; Page et al. 2000) and the Delamerian ( 520$490 \mathrm{Ma}$; Harrison and McDougall 1981) orogenies (e.g., Raetz et al. 2002a; Noble et al. 2003; Forbes and Betts 2004; Gibson and Nutman 2004).

The Olarian Orogeny was an episode of major midcrustal basin inversion involving polyphase deformation and metamorphism. The timing of the Olarian Orogeny has been tightly constrained to between $1597 \pm 3$ and $1591 \pm 5 \mathrm{Ma}$ (Page et al. 2000, 2005). Metamorphic conditions attained upper amphibolite to granulite facies conditions, peaking at $1600 \pm 8 \mathrm{Ma}$ (Page and Laing 1992). Early stages of the Olarian Orogeny involved development of large-scale recumbent to shallowly inclined sheathlike folds during thin-skinned deformation (Marjoribanks et al. 1980; Hobbs et al. 1984; Forbes et al. 2004). These were overprinted by approximately northeast-trending upright folds developed during thick-skinned deformation (Marjoribanks et al. 1980; Hobbs et al. 1984; Forbes and Betts 2004; Forbes et al. 2004).

The Broken Hill Block later formed the basement of Neoproterozoic rift and passive margin sediments of the Adelaidean cover sequences. These sediments were deposited at ca. 830-780 Ma (Preiss $2000 b$ ). The Adelaidean sequences and Broken Hill Block basement were subsequently deformed and metamorphosed to greenschist facies during the Delamerian Orogeny (Preiss 2000a) at ca. 520-490 Ma (Harrison and McDougall 1981).

\section{The Round Hill Area}

A layer-parallel high-temperature shear zone that accommodated early deformation within the Broken Hill Block has been previously described in the Round Hill Area (figs. 1, 2; Forbes et al. 2005). The shear zone is northeast trending and moderately northwest dipping (fig. 2), and it preserves welldeveloped kinematic indicators such as S-C fabrics and sheared porphyroblasts, as well as a moderately to well-developed sillimanite + biotite mineral lineation (Forbes et al. 2005). Pelitic gneiss exposed to the south of the shear zone has had high partial melt content and preserves well-defined quartzo- feldspathic leucosome layers (fig. 2), and it corresponds stratigraphically to the Thackaringa Group and middle to upper parts of the Broken Hill Group (fig. 1; Bradley 1980). Rock packages to the north of the shear zone consist of interbedded psammite and pelite units (fig. 2) and are from the Sundown Group (fig. 1; Bradley 1980). Activity along the shear zone is related to the development of the regionally pervasive high-temperature fabric (termed S2), which developed before the first recognized folding event (D3) within the Round Hill Area. D3 is attributed to early stages of the Olarian Orogeny (Forbes et al. 2005). Development of the shear zone and S2 fabric appears to be closely related to peak granulite facies metamorphism associated with growth of a coarse-grained garnet + cordierite + K-feldspar + sillimanite mineral assemblage (fig. 3) within pelitic units (Forbes et al. 2005). The coarsegrained peak assemblage postdates an inclusion assemblage ( $\mathrm{S} 1$; fig. 3 ) interpreted to represent early rifting within the Broken Hill Block at either ca. 1690-1670 Ma, during basin evolution and deposition of the Willyama Supergroup, or 1640-1610 $\mathrm{Ma}$, just before the Olarian Orogeny (Forbes et al. 2005).

The absolute timing of activity along the layerparallel D2 shear zone is unresolved, as is its absolute temporal relationship to peak granulite facies metamorphism. Additionally, the timing of the tectonothermal event (M1/D1; Forbes et al. 2005) that occurred before the development of the hightemperature shear zones and is preserved as inclusions within peak metamorphic porphyroblasts is poorly constrained. The impact this early event had on the D2 event is also poorly understood. Temporal constraint on the timing of the D1 event will have implications for modeling how the thermal regime of this early rift event influenced the thermal regime of the D2 event and subsequent orogenesis (Olarian Orogeny at ca. 1600-1590 Ma; Page et al. 2000).

Context of Samples. In situ U-Pb SHRIMP monazite analysis was undertaken on two samples within the Round Hill Area (fig. 2) to constrain the absolute timing of development of the pervasive shear-related S2 fabric and to relate this to the timing of peak granulite facies metamorphism. The first sample (RHA51; Australian Map Grid [AMG] coordinates: easting $548904 \mathrm{mE}$, northing 6467250 $\mathrm{mN}$; fig. 2) was taken from a pelite within the hightemperature shear zone (Forbes et al. 2005), and a second sample (RHA58; AMG: easting $548641 \mathrm{mE}$, northing $6468640 \mathrm{mN}$; fig. 2) was taken from a pelite $\sim 300 \mathrm{~m}$ north-northwest of the shear zone. Fab- 

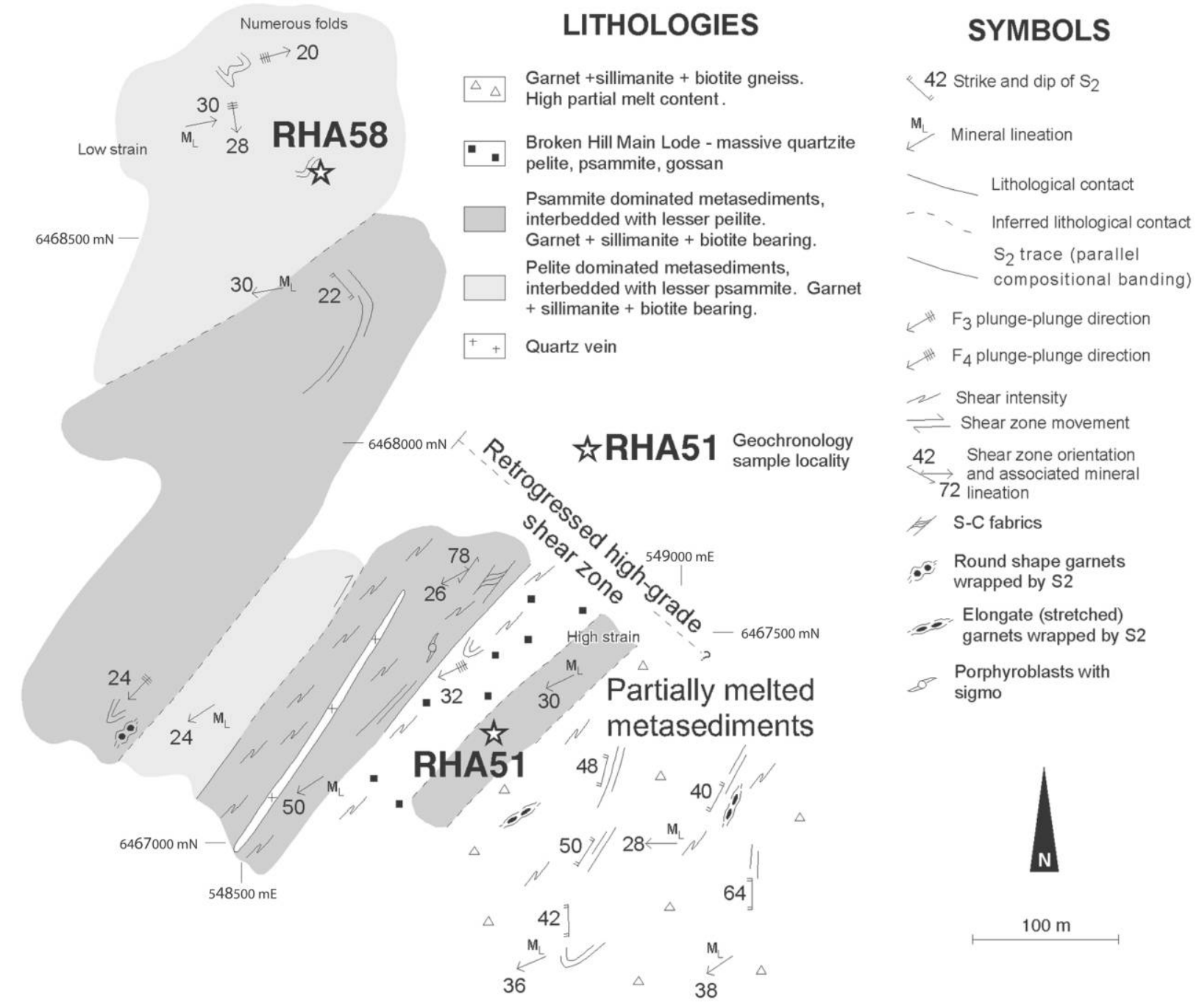

Figure 2. Simplified geological map of the Round Hill Area (modified after Forbes et al. 2005), showing localities of geochronology samples RHA51 and RHA58.

ric and petrogenetic relationships, as well as the $P T$ evolution of these pelites, have been described in detail by Forbes et al. (2005).

A distinct advantage of in situ isotopic analysis is that the texture and fabric relationships of the geochronometer can be determined. Targeting monazite within a fabric to constrain the timing of fabric development has also been applied in other studies (e.g., Williams et al. 1999; Shaw et al. 2001). Two types of monazite were recognized and analyzed in this study. The first group was selected from within the dominant S2 fabric within the pelites, with the intention of constraining the timing of development of this fabric. Monazite crystals that were elongate in the orientation of the fabric or that appeared to have grown with the S2 mineral assemblage (dominantly fibrolitic sillimanite) were selected (fig. $4 a-4 h$ ). Monazite within the S2 fabric characteristically has highly irregularly shaped grain boundaries (fig. $4 c, 4 d, 4 g, 4 h$ ). The second group of monazite was taken from within coarsegrained garnet, biotite, and K-feldspar minerals that comprise the peak granulite facies mineral assemblage within the pelites (fig. 4i-41). Because monazite inclusions can be armored from isotopic disturbance during later events (Montel et al. 2000), this group was targeted to identify any older monazite populations that may have been protected from the effects of later deformation and metamorphism. Monazite inclusions targeted within 


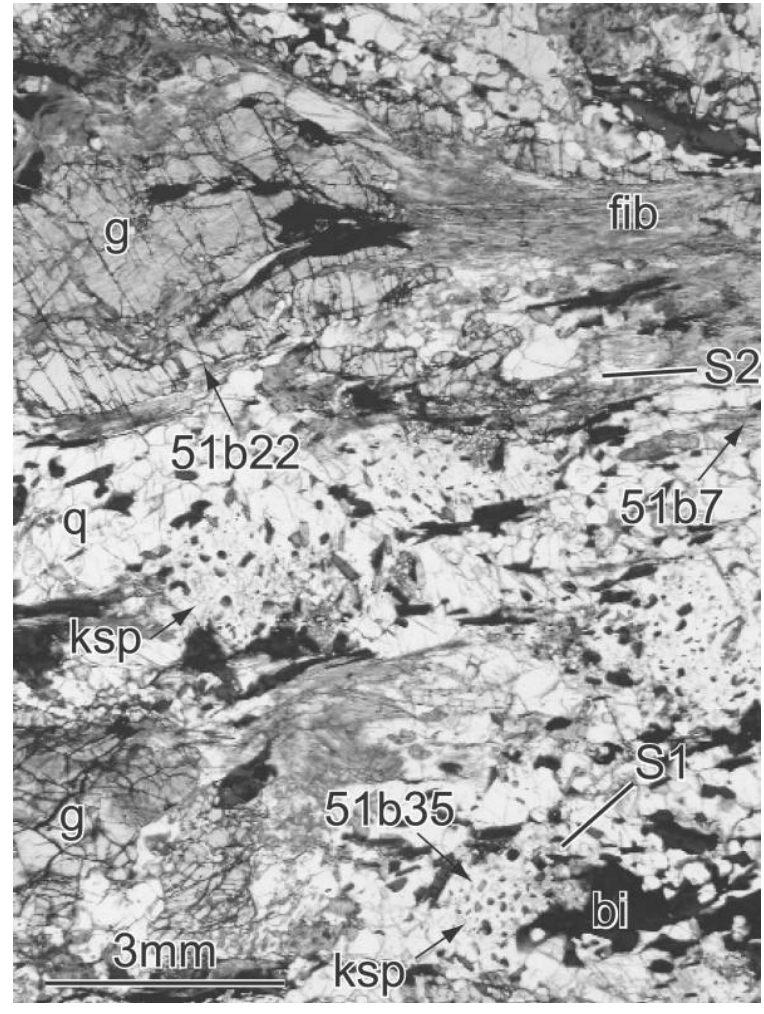

Figure 3. Photomicrograph of sample RHA51, showing an example of M2 porphyroblasts (K-feldspar and garnet in this example) and the S2 fabric. The S2 fabric is defined by fibrolitic sillimanite and biotite. Fine-grained biotite defining the $\mathrm{S} 1$ inclusion assemblage is preserved within the K-feldspar grains. The fabric has a similar orientation within multiple K-feldspar grains across the photomicrograph. The location of some analyzed monazite grains is shown. $b i=$ biotite; fib $=$ fibrolitic sillimanite; $g=$ garnet; $k s p=\mathrm{K}$-feldspar; $q=$ quartz. See also Forbes et al. (2005). The location of sample RHA51 is shown in figure 2 .

the garnets were located from the center to near the boundary of the grains. Because the garnet grains within the Round Hill Area have been chemically homogenized during high-temperature peak metamorphism (Forbes et al. 2005), identification of monazite inclusions that may occupy different zones within the garnet is not possible. The grain boundaries of monazite preserved as inclusions within the coarse-grained minerals are mostly regular, and the grains are typically rounded or ellipsoidal in shape (fig. 4j, 41).

\section{U-Pb Monazite Geochronology}

Geochronological Analysis. U-Th- $\mathrm{Pb}$ isotopic ratios and concentrations of monazite were analyzed in situ on polished thin sections by using the sensitive high-resolution ion microprobe (SHRIMP-II) at the John de Laeter Centre for Mass Spectrometry, Curtin University, Western Australia. The SHRIMP technique was chosen because it has long been considered a robust method for U-Th- $\mathrm{Pb}$ isotopic analysis and produces ages with reasonably small errors, which was critical in this study to distinguish between ages that are as little as 20 million years apart. For the analysis, a beam size of $\sim 15 \mu \mathrm{m}$ was used, and monazite grains down to $20 \mu \mathrm{m}$ were targeted. The monazite standard "MAD" (514 Ma: ${ }^{206} \mathrm{~Pb} /{ }^{238} \mathrm{U}=0.0830238206$ ) was analyzed periodically in a separate mount during collection of the Round Hill data for reference and cross-checking. The data were processed and reduced using P. D. Kinny's KRILL software.

Backscattered Electron Imaging. Backscattered electron (BSE) imaging using the scanning electron microscope facilities at Melbourne University and reflected-light microscopy allowed recognition and petrological analysis of monazite inclusions and within the matrix of the samples. BSE imaging also allowed detection of small heterogeneities within individual grains (fig. 4), which may (e.g., Shaw et al. 2001) or may not (e.g., Clark et al. 2005) reflect age variations. There is a concern that heterogeneities due to $\mathrm{Y}$ variations may go undetected within high-Th monazites when using only BSE imaging and that compositional mapping of monazites should be done. However, the monazites analyzed in this study can be considered to have normal Th content $(3 \%-7 \% \mathrm{Th})$, with one grain recording higher Th content $(10 \% \mathrm{Th})$, implying that any heterogeneities within the monazite grains in the Round Hill Area can be seen using BSE imaging. BSE imaging alone has been used in many cases to detect zonation within monazite grains (e.g., Zhu and O'Nions 1999; Catlos et al. 2002; Clark et al. 2005; Rutherford et al. 2006).

Some small heterogeneities can be seen in the monazite grains from the Round Hill Area (fig. 4); however, these are much smaller than the $\sim 15-\mu \mathrm{m}$ beam size used on the SHRIMP. All ages obtained from the SHRIMP analysis (except for spot 51b17) were concordant or close to concordant (fig. 5a), suggesting that the small heterogeneities do not reflect age variations within the monazite grains.

Geochronology Results. Sample RHA51. Twenty-four analyses were taken from sample RHA51. Analyses were done on monazite grains residing in two textural locations, within the dominant fabric (S2) or within the coarse-grained peak assemblage. Data analysis $51 \mathrm{~b} 49$ (table A1, available in the online edition or from the Journal of 
Geology office) was rejected because of low count values.

Six analyses were taken from within the $\mathrm{S} 2$ fabric (tables 1, A1) and are presented as a weighted average plot in figure $5 b$. The calculated weighted age is $1592 \pm 4 \mathrm{Ma}$ (fig. $5 b$ ).

Seventeen analyses were taken from monazite inclusions within the coarse-grained assemblage (tables 1, A1) and are presented as a probability plot in figure 5c. Analysis $51 \mathrm{~b} 17$ is an outlier (fig. 5c, $5 d$; table A1) and was not used to calculate weighted ages. The weighted average age of the remaining data from the monazite inclusions is $1601 \pm 6 \mathrm{Ma}$, which gives a large MSWD value (8.9) and low probability (0.000), indicating a statistically unreasonable age. The probability plot (fig. 5c) shows an age population break within the analyzed monazite inclusions at $\sim 1611 \mathrm{Ma}$. Data from the monazite inclusions were separated into two groups based on the textural locality of the grains (table 1). The first group is represented by monazite grains that are completely enclosed within garnet, alkali feldspar, or biotite host minerals (table 1). The weighted average age for these monazite grains is $1619 \pm 4 \mathrm{Ma}$ (fig. $5 d$ ). Locally, sillimanite inclusions were observed within some older monazite grains hosted within garnet porphyroblasts; however, they do not appear to have affected the U-Pb isotopic ratios of the older grains.

The second group of monazite grains is in contact with fractures within the host mineral or at grain boundaries (table 1). These monazite grains give a weighted average age of $1596 \pm 5 \mathrm{Ma}$, which gives a high MSWD value (4.6) and low probability (0.000). Within the partially enclosed monazite group, spot $51 \mathrm{~b} 19 \mathrm{~b}$ may be considered an outlier (fig. $5 d)$ and yields an age (1624 $\pm 6 \mathrm{Ma}$; table A1) that is more consistent with the 1619-Ma enclosed monazite population (table 1). A second spot on this grain (spot 51b19a; fig. $4 m, 4 n$ ) yielded an age of $1598 \pm 3 \mathrm{Ma}$ (table A1), which is consistent with the partially enclosed inclusions with which it is grouped (table 1). These analyses highlight the possibility for heterogeneous isotopic disturbance by fluid-assisted recrystallization or isotopic resetting within the individual monazite grains. With analysis $51 \mathrm{~b} 19 \mathrm{~b}$ considered an outlier, the recalculated weighted average age for the partially enclosed monazite group is $1595 \pm 4 \mathrm{Ma}$, which also gives more statistically meaningful results $($ MSWD $=$ 2.4, $P=0.012$ ).

Sample RHA58. Six analyses were done on monazite grains in the dominant S2 fabric in sample RHA58 (table 1). This population yielded concordant or close to concordant ages (fig. 6a). A single-age population is assumed because the ${ }^{207} \mathrm{~Pb} /$ ${ }^{206} \mathrm{~Pb}$ ages are within error of each other and because the monazite grains are all from within the S2 fabric (table 1). The calculated weighted age for monazite within the S2 fabric of sample RHA58 is $1606 \pm 7 \mathrm{Ma}$ (fig. 6b).

\section{Discussion}

Armoring of Monazite Inclusions. The preservation of the 1619-Ma age monazite grains enclosed within the coarse-grained assemblage is considered to be due to armoring of the monazite inclusions against disturbance of the U-Th-Pb system (Montel et al. 2000), which may occur by isotopic resetting (e.g., Montel et al. 2000) or fluid-assisted recrystallization processes (e.g., Catlos et al. 2002; Harlov et al. 2005). The younger age population of monazite inclusions (1596 $\pm 5 \mathrm{Ma}$ ) also hosted within the coarse-grained peak metamorphic mineral assemblage and adjacent to grain boundaries or fractures within the host mineral may have grown with the older 1619-Ma monazite population. However, the younger monazite grains were not completely armored during later deformation and metamorphic events and may have been affected by dissolution-precipitation processes or isotopic resetting.

The older age for monazite grains enclosed within coarse-grained minerals may be argued to be a mixing age between potential 1690-1670-Ma monazite ages associated with early rifting and deposition of the Willyama Supergroup and younger 1600-1590-Ma monazite ages associated with the D2 event and the Olarian Orogeny. The 1619-Ma monazite age obtained in this study is not considered a mixing age because the ages are concordant, and the probability plot shows a clear, sharp peak that is not skewed at 1619 Ma.

Relative Timing of Growth of Inclusions and CoarseGrained Peak Assemblage. The minerals hosting the monazite inclusions are representative of the peak metamorphic assemblage within the Round Hill pelites (Forbes et al. 2005). Garnet porphyroblasts that are part of the high-grade metamorphic assemblage have been directly dated from other areas of the Curnamona Province. Lead step leaching of garnet porphyroblasts from the Southern Cross Area (fig. 1) yielded oldest ages of $1599 \pm 2.5$ and $1594 \pm 7 \mathrm{Ma}$ (Tonelli et al. 2002). Sm-Nd dating of garnet porphyroblasts from the Walparuta Inlier in the neighboring Olary Domain gave ages of $1609 \pm 8,1583 \pm 6$, and $1583 \pm 5 \mathrm{Ma}$ (Hand et al. 2003). In addition, the timing of peak metamorphism within the Broken Hill Block has been constrained to $1600 \pm 8 \mathrm{Ma}$ through SHRIMP U-Pb 

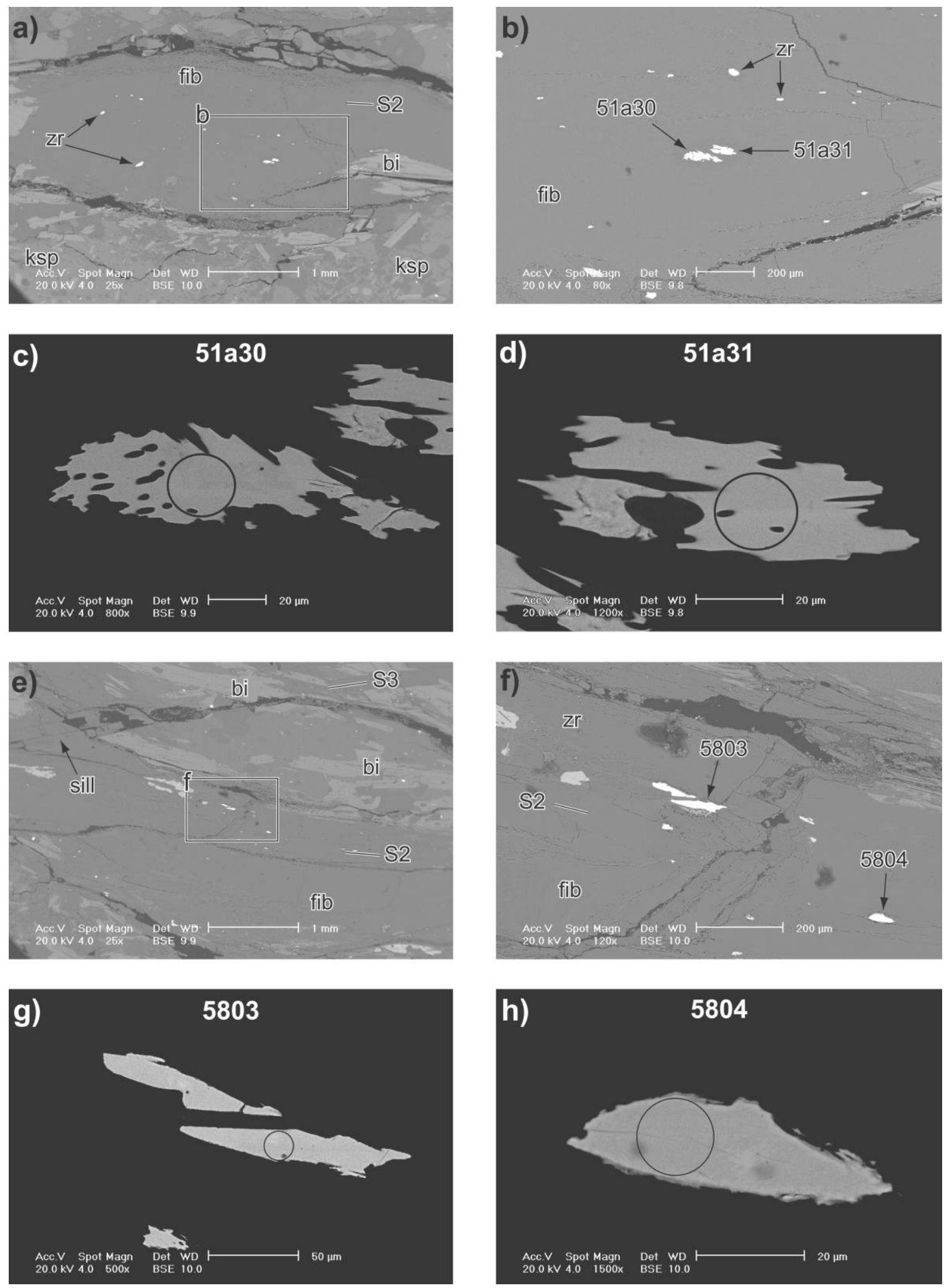

Figure 4. Selected backscattered electron images of analyzed monazite grains from the Round Hill pelites. (Sample localities shown in fig. 2). $a-d$, Typical monazite within the S2 fabric of sample RHA51. $e-h$, Typical monazite within the S2 fabric of sample RHA58. $i, j$, Monazite inclusion completely enclosed by the garnet porphyroblast within 
dating of zircon (Page and Laing 1992). These garnet ages most likely indicate the timing of closure of these isotopic systems during the early stages of cooling from peak temperatures. This allows for two possible interpretations for the 1619-Ma age of the enclosed monazite grains: $(a)$ that they grew during the prograde path, contemporaneously with the growth of the coarse-grained assemblage, or $(b)$ that they grew in a separate thermal event that predated peak metamorphism.

Timing of Activity of High-Temperature Shear Zones. Monazite oriented within the S2 fabric preserved in the Round Hill pelites yielded ages of $1592 \pm 7 \mathrm{Ma}$ (sample RHA51) and $1606 \pm 7 \mathrm{Ma}$
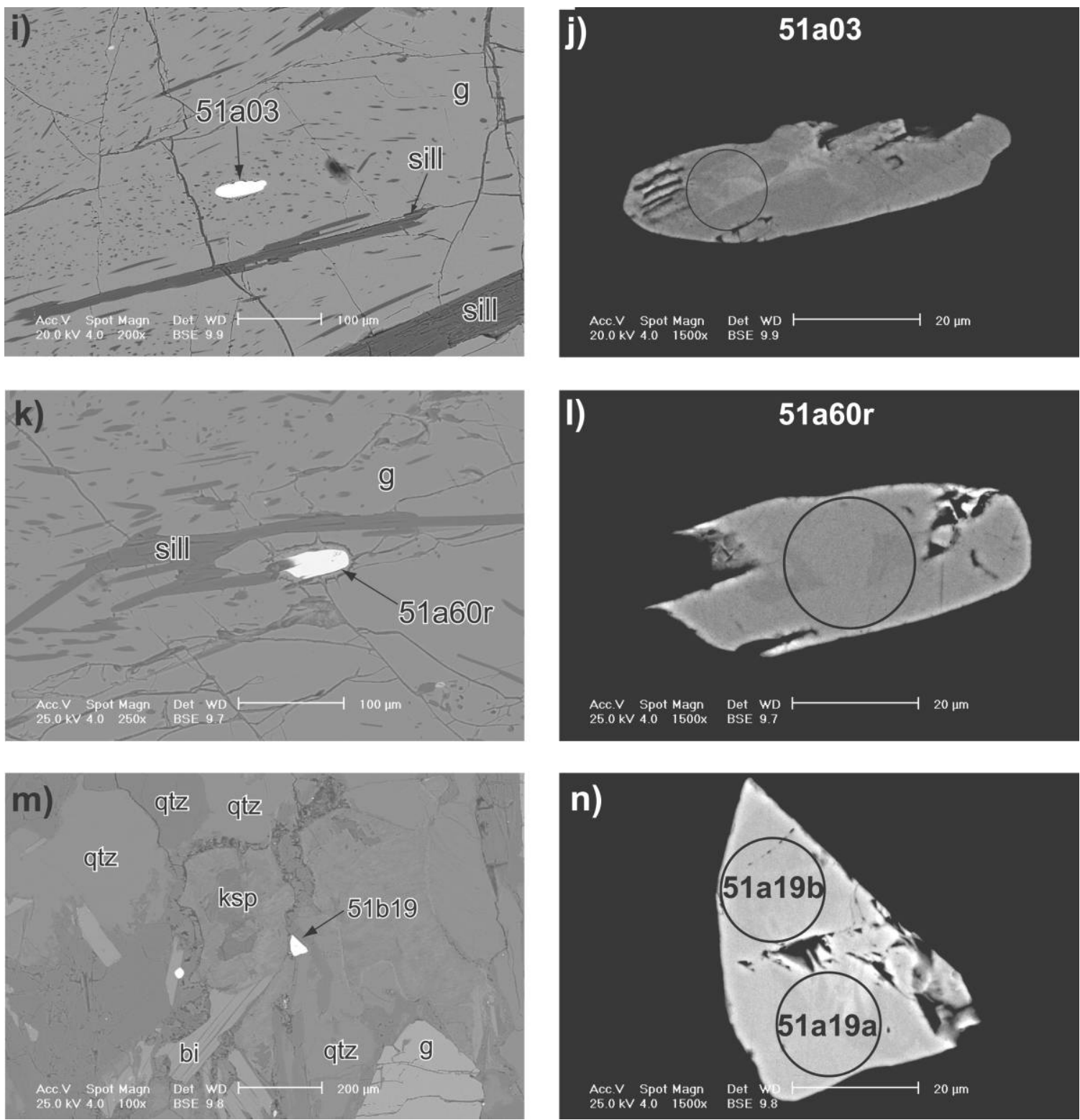

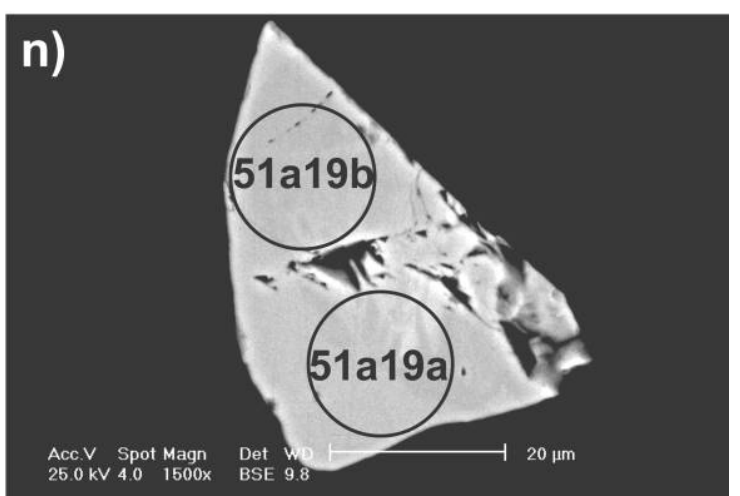

sample RHA51; representative of the older 1619-Ma monazite population identified within the coarse-grained peak metamorphic mineral assemblage. $k, 1$, Monazite inclusion within a garnet porphyroblast proximal to a crack from sample RHA51; representative of the younger $~ 1600-\mathrm{Ma}$ monazite population identified within the coarse-grained peak metamorphic assemblage. $m, n$, Partially enclosed monazite inclusion within sample RHA51; the two spots yielded differing ages highlighting the possibility of heterogeneous isotopic disturbance of the monazite grains. $b i=$ biotite $; f i b=$ fibrolite; $g=$ garnet; $k s p=\mathrm{K}$-feldspar; $q t z=$ quartz; sill = sillimanite; $z r=$ zircon. The textural localities of the monazite grains are also shown in table 1. 

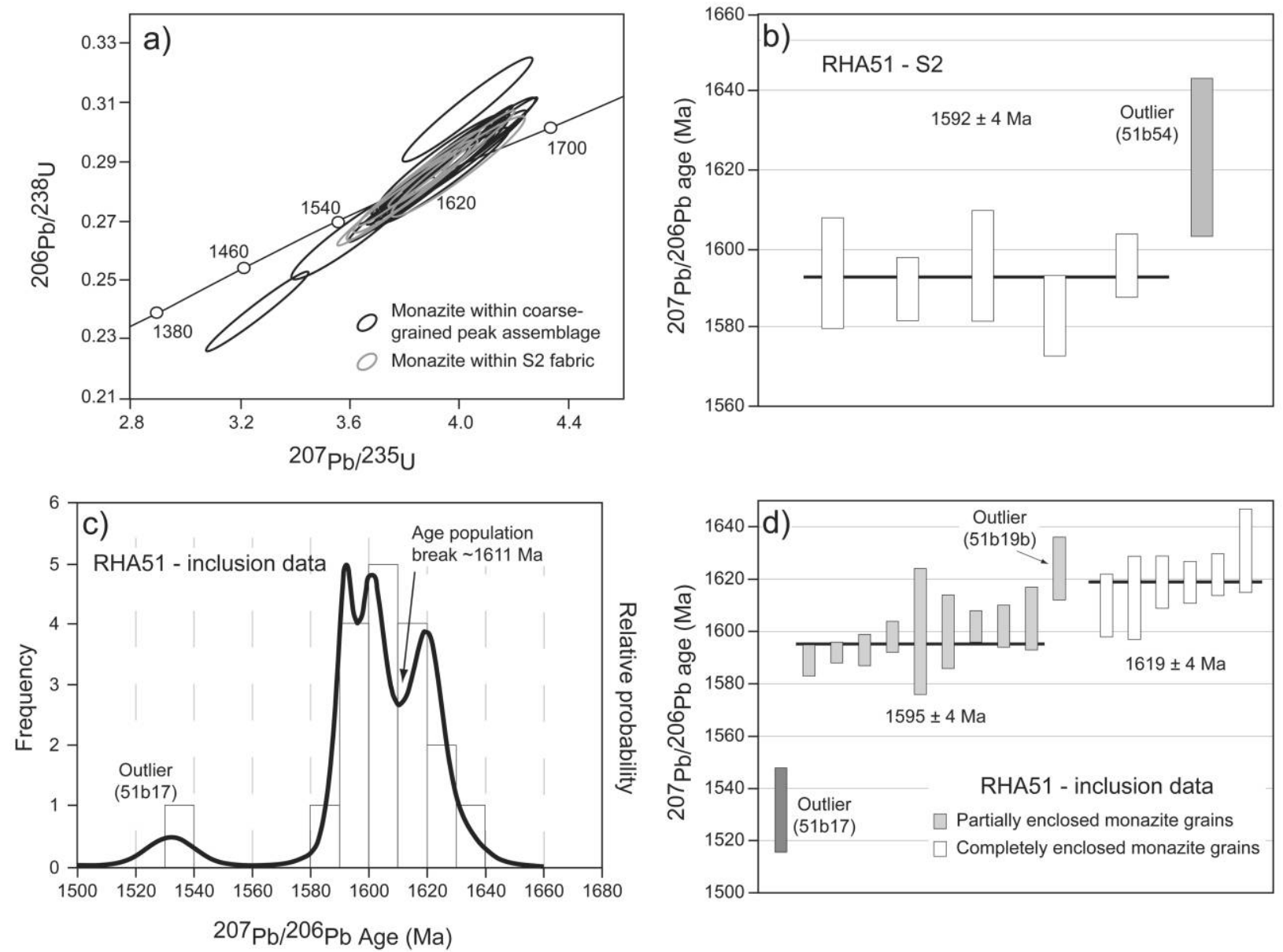

Figure 5. Geochronology results for sample RHA51. Sample locality is shown in figure 2. $a$, Concordia plot of all analyses of sample RHA51. $b$, Weighted average plot of data from monazite analyzed within the S2 fabric. Box heights are $2 \sigma$. The gray bar is an $1623-$ Ma outlier (spot 51b54) that was excluded from the weighted mean age calculations. Mean age $=1592 \pm 4 \mathrm{Ma}, \mathrm{MSWD}=1.2, P=0.30 . c$, Cumulative probability plot of data from monazite grains that occur as inclusions within the peak mineral assemblage. A break in age populations can be seen at $\sim 1611 \mathrm{Ma}$. $d$, Weighted average plot of data from monazite occurring as inclusions within the coarse-grained peak metamorphic assemblage. Box heights are $2 \sigma$. The older population is represented by white bars, the younger population by light gray bars. The dark gray bar is an $\sim 1532$-Ma outlier (spot 51b17) that was excluded from weighted age calculations. Mean age of older population (>1611 Ma; enclosed monazite grains) $=1619 \pm 4 \mathrm{Ma}$, MSWD $=1.07, P=0.38$. Mean age of younger population $(<1611 \mathrm{Ma}$; partially enclosed monazite grains $)=1595 \pm 4 \mathrm{Ma}$, MSWD $=2.4, P=0.012$. Weighted average ages were calculated to 95\% confidence using the Isoplot program (Ludwig 2000).

(sample RHA58). The closure temperature for the $\mathrm{U}-\mathrm{Pb}$ isotopic system of unarmored monazite has long been considered to be $720^{\circ}-750^{\circ} \mathrm{C}$ (Copeland et al. 1988; Parrish 1990), which is very close to the conditions of peak metamorphism lat least $740^{\circ} \mathrm{C}$ at $\sim 5 \mathrm{kbar}$; Powell and Downes 1990; Forbes et al. 2005). This infers that the $\sim 1600$-Ma ages obtained from monazite within the matrix may have been isotopically reset, or they may also represent new growth and approximate the time of S2 fabric development.

However, more recently, Cherniak et al. (2004) suggested that the closure temperature for monazite is much higher and may be up to $950^{\circ} \mathrm{C}$ for a $20-\mu \mathrm{m}$ grain in a cooling environment of $10^{\circ} \mathrm{C} / \mathrm{Ma}$. In this case, disturbance of the U-Th-Pb system is not attributed to isotopic resetting but to fluidmediated dissolution and precipitation process of the monazite (e.g., Teufel and Heinrich 1997; Cherniak et al. 2004; Harlov et al. 2005). The 1600-Ma monazite population may represent isotopic disturbance by fluid-assisted recrystallization of older grains that were not armored by porphyroblastic grains. 
Table 1. Textural Localities of Analyzed Monazite Grains

\begin{tabular}{|c|c|c|}
\hline Spot no. & Monazite locality & Mean age $(\mathrm{Ma})$ \\
\hline \multicolumn{3}{|c|}{ Sample RHA58: } \\
\hline 5803 & Within S2 & \\
\hline 5804 & Within S2 & \\
\hline 5826 & Within S2 & $1606 \pm 7$ \\
\hline 5828 & Within S2 & \\
\hline 5830 & Within S2 & \\
\hline 5833 & Within S2 & \\
\hline \multicolumn{3}{|c|}{ Sample RHA51: } \\
\hline \multicolumn{3}{|c|}{ S2 fabric: } \\
\hline $51 \mathrm{a} 30$ & Within S2 & \\
\hline $51 \mathrm{a} 31$ & Within S2 & \\
\hline $51 \mathrm{~b} 7 \mathrm{a}$ & Within S2 & $1592 \pm 4$ \\
\hline $51 \mathrm{~b} 7 \mathrm{~b}$ & Within S2 & \\
\hline $51 \mathrm{~b} 22$ & Within S2, at edge of garnet porphyroblast & \\
\hline $51 \mathrm{~b} 54$ & Within S2 & \\
\hline \multicolumn{3}{|c|}{$\begin{array}{l}\text { Inclusions within coarse-grained } \\
\text { peak mineral assemblage: }\end{array}$} \\
\hline $51 \mathrm{~b} 17$ & With quartz/K-feldspar grains, at grain boundary & \\
\hline $51 \mathrm{~b} 19 \mathrm{~b}$ & With quartz/K-feldspar grains, at grain boundary & \\
\hline $51 \mathrm{a} 34$ & Within garnet, far edge close to fracture & \\
\hline $51 a 55$ & Within garnet, at grain boundary & \\
\hline $51 \mathrm{a} 60 \mathrm{r}$ & Within garnet, close to fracture and sill inclusion & \\
\hline $51 a 68$ & Within K-feldspar, at boundary of quartz inclusion & $1595 \pm 4$ \\
\hline $51 \mathrm{~b} 19 \mathrm{a}$ & With quartz/K-feldspar grains, at grain boundary & \\
\hline $51 \mathrm{~b} 35$ & Within K-feldspar, at boundary of quartz inclusion & \\
\hline $51 \mathrm{~b} 45.1$ & Within garnet, at grain boundary & \\
\hline $51 \mathrm{~b} 45.2$ & Within garnet, at grain boundary & \\
\hline $51 \mathrm{~b} 46$ & Within garnet, at grain boundary & \\
\hline $51 \mathrm{a} 03$ & Within garnet, enclosed & \\
\hline $51 \mathrm{a} 10$ & Within garnet, enclosed, close to sill inclusions & \\
\hline $51 \mathrm{a} 53 \mathrm{a}$ & Within biotite, enclosed but near cleavage plane & $1619 \pm 4$ \\
\hline $51 \mathrm{a} 53 \mathrm{~b}$ & Within biotite, enclosed, near cleavage plane & \\
\hline $51 \mathrm{~b} 52$ & Within garnet, enclosed, some sill inclusions & \\
\hline $51 \mathrm{~b} 59$ & Within K-feldspar, enclosed, near sill inclusions & \\
\hline
\end{tabular}

Unequivocal absolute dating of the D2 event in the Round Hill Area is currently difficult. Because the conditions of peak metamorphism in the Broken Hill Block are very close to suggested closure temperatures of monazite and processes of fluidmediated dissolution-precipitation of monazite are now considered to be more prevalent than had previously been thought (e.g., Teufel and Heinrich 1997; Cherniak et al. 2004; Harlov et al. 2005), disturbance of the $\mathrm{U}-\mathrm{Th}-\mathrm{Pb}$ isotopic system within unarmored monazite in the Round Hill Area is likely. However, relative time constraints on D2 deformation can be considered. The pervasive S2 fabric mapped in the Round Hill Area (fig. 2) is related to activity along high-temperature shear zones (Forbes et al. 2005) that developed at or just after peak metamorphism (1600 $\pm 8 \mathrm{Ma}$; Page and Laing 1992). The high-temperature shear zones and S2 fabric are overprinted by folds developed during the Olarian Orogeny (Forbes et al. 2005), the onset of which was immediately after the D2 event and peak metamorphism at $1597 \pm 3 \mathrm{Ma}$ (Page et al.
2005). The relative timing of peak metamorphism and the onset of the Olarian Orogeny constrains the timing of the S2 fabric development and activity along high-temperature shear zones to 1600 $\mathrm{Ma}$, which is also the approximate time of recrystallization and/or isotopic resetting of the matrix monazite grains within the S2 fabric in the Round Hill pelites.

Thermal Evolution of the Broken Hill Block before the Olarian Orogeny. The early history of the Broken Hill Block has been previously envisaged as involving an early rift event at ca. 1710-1670 Ma that resulted in the opening of a basin into which lower units of the Broken Hill stratigraphy were deposited (e.g., Stevens et al. 1988; Page et al. 2000). Rifting was followed by sag-phase sedimentation and deposition of the Paragon Group (fig. 1) at least until $1640 \mathrm{Ma}$ (Page et al. 2000) and possibly until $1600 \mathrm{Ma}$ (Raetz et al. 2002b); however, this is not known because the uppermost sediments of the Paragon Group have since been removed by erosion. 

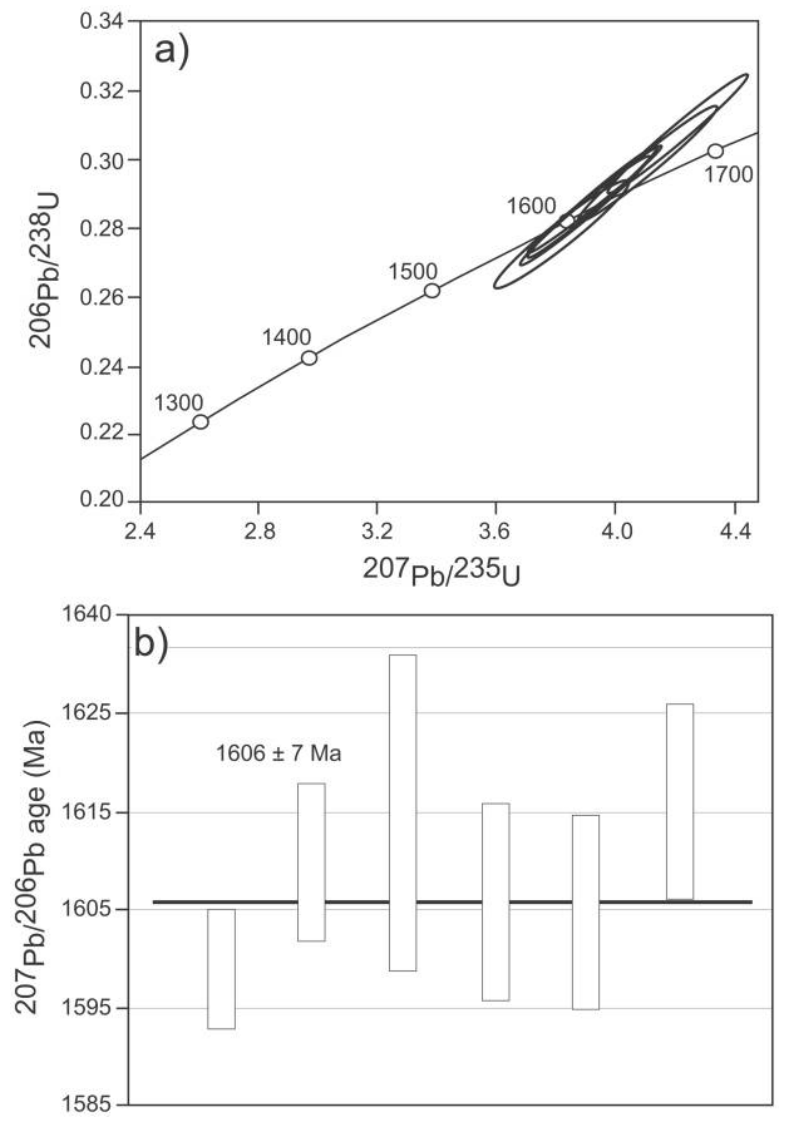

Figure 6. Geochronology results for sample RHA58 (sample locality shown in fig. 2). $a$, Concordia plot of all analyses of sample RHA51. $b$, Weighted average plot of data from monazite analyzed within the S2 fabric. Box heights are $2 \sigma$. Mean age $=1606 \pm 7 \mathrm{Ma}, \mathrm{MSWD}=2.3$, $P=0.038$. Weighted average ages were calculated to $95 \%$ confidence using the Isoplot program (Ludwig 2000).

Using SHRIMP U-Pb dating of zircon, Nutman and Ehlers (1998) also identified a zircon age population at 1660-1640 Ma. This event was interpreted to be a thermal pulse that resulted in amphibolite to granulite facies metamorphism and development of melt segregations within lower parts of the Willyama Supergroup. Teale and Fanning (2000) also recognized a $1630-$ Ma monazite age population using in situ SHRIMP U-Pb analysis, and they attributed this to a major albitization event. The distinction of these age populations has not been widely accepted because they have not been readily reproduced and might represent a mixing age (e.g., Page et al. 2000, 2005; Stevens 2000). However, in this study, two separate monazite age populations that are also texturally discrete have been identified, 1619 and $\sim 1600 \mathrm{Ma}$, indicating that there was an event between early basin evolution and deposition of the Willyama Supergroup (ca. 1690-1640 Ma; e.g., Stevens et al. 1988) and the Olarian Orogeny (ca. 1600-1590 Ma; Page et al. 2000). While the younger age is related to monazite growth/resetting during high-temperature shear zone activity at peak granulite facies metamorphic conditions, the significance of the age of the older shielded monazite inclusions remains to be considered.

Forbes et al. (2005) reported an inclusion assemblage of sillimanite + biotite + quartz + plagioclase \pm muscovite within coarse-grained cordierite, alkali feldspar, and garnet that comprise the peak mineral assemblage within the rocks. This inclusion assemblage is interpreted to represent an early metamorphic event, termed $M 1$, and it developed at amphibolite facies conditions (at least $600^{\circ} \mathrm{C}$ and $\sim 2.8-4.2 \mathrm{kbar}$; Forbes et al. 2005). These pressures and temperatures are favorable for the initial growth of metamorphic monazite, which forms at lower amphibolite facies conditions (e.g., Kingsbury et al. 1993). The monazite inclusions hosted within the peak metamorphic assemblage are interpreted to have grown with the M1 mineral assemblage at amphibolite facies conditions and therefore can be used to constrain the timing of prograde amphibolite facies metamorphism in the Round Hill Area to around 1619 Ma.

The recognition of a thermal event before $\sim 1600$ Ma within the Broken Hill Block supports the work of Nutman and Ehlers (1998); however, we suggest that this event reached only amphibolite, not granulite, facies conditions. Whether the 1660-1640Ma thermal pulse postulated by Nutman and Ehlers (1998) is related to the M1 amphibolite facies event is uncertain. Furthermore, because we have no evidence of a decrease in temperature between the M1 amphibolite facies event and the M2 peak granulite facies metamorphism at $1600 \mathrm{Ma}$ (Page and Laing 1992), the M1 event may not be a distinct thermal "pulse" sensu stricto (akin to that described by Nutman and Ehlers [1998]) but may rather represent a small section of the prograde path of the Round Hill pelites. Forbes et al. (2005) suggested that the M1 amphibolite facies event was associated with elevated geothermal gradients and attributed to early extension. The results presented in this study have shown that this event occurred at $1619 \mathrm{Ma}$, implying an extensional event just before peak high-temperature/low-pressure granulite facies metamorphism and intense crustal orogenesis at $\sim 1600 \mathrm{Ma}$ within the Broken Hill Block. It is possible that elevated temperatures of the 1619-Ma event may have been carried over into peak high-temperature/low-pressure meta- 
morphism within the Broken Hill Block and may have affected the thermal regime of the crust during orogenesis; however, the intensity and longevity of the event now require consideration (Forbes et al., forthcoming).

\section{Conclusions}

Two monazite age populations were identified using in situ SHRIMP U-Pb analysis on pelite samples within and proximal to an early-formed hightemperature shear zone in the southern Broken Hill Block. The older population yielded an age of 1619 $\mathrm{Ma}$ and was obtained from monazite inclusions that are completely enclosed within coarse K-feldspar or garnet grains. These host minerals form part of the peak metamorphic mineral assemblage within the pelites and armored the enclosed monazite inclusions against the effects of later deformation and metamorphic events. This age is interpreted to represent the timing of prograde amphibolite facies metamorphism within the Bro- ken Hill Block. The younger monazite population yielded an age of $\sim 1600 \mathrm{Ma}$ and was obtained from monazite within the matrix of the pelites and from monazite inclusions that were adjacent to fractures within or in contact with the grain boundaries of hosting K-feldspar or garnet grains. This younger population is interpreted to represent a later stage of monazite growth and/or isotopic resetting of the monazite during deformation accommodated along high-temperature shear zones and peak granulite facies metamorphism.

\section{A C K N O W L E D G M E N T S}

This article is published with the permission of the Predictive Mineral Discovery Cooperative Research Centre. John Clulow is thanked for his assistance in the field. Mike Williams and Paul Evins are thanked for constructive reviews of the manuscript. Alfred Anderson is thanked for his editorial handling of the manuscript.

\section{R E F E R E N C E S C I T E D}

Bradley, G. M. 1980. Mount Gipps. Geol. Surv. New South Wales, Geological Sheet 7234 III S, scale $1: 25,000$.

Catlos, E. J.; Gilley, L. D.; and Harrison, T. M. 2002. Interpretation of monazite ages obtained via in situ analysis. Chem. Geol. 188:193-215.

Cherniak, D. J.; Watson, E. B.; Grove, M.; and Harrison, T. M. 2004. Pb diffusion in monazite: a combined RBS/ SIMS study. Geochim. Cosmochim. Acta 68:829-840.

Clark, C.; Schmidt Mumm, A.; and Faure, K. 2005. Timing and nature of fluid flow and alteration during Mesoproterozoic shear zone formation, Olary Domain, South Australia. J. Metamorph. Geol. 23:147-164.

Copeland, P.; Parrish, R. R.; and Harrison, T. M. 1988. Identification of inherited radiogenic $\mathrm{Pb}$ in monazite and implications for U-Pb systematics. Nature 333: 760-763.

Forbes, C. J., and Betts, P. G. 2004. Development of type 2 fold interference patterns in the Broken Hill Block: implications for strain partitioning across a detachment during the Olarian Orogeny. Aust. J. Earth Sci. 51:173-188.

Forbes, C. J.; Betts, P. G.; Giles, D.; and Weinberg, R. Forthcoming. Reinterpretation of the tectonic context of high-temperature metamorphism in the Broken Hill Block, NSW, and implications on the Palaeo- to Meso-Proterozoic evolution. Precambrian Res.

Forbes, C. J.; Betts, P. G.; and Lister, G. S. 2004. Synchronous development of type 2 and type 3 fold interference patterns: evidence for recumbent sheath folds in the Allendale Area, Broken Hill, NSW, Australia. J. Struct. Geol. 26:113-126.
Forbes, C. J.; Betts, P. G.; Weinberg, R.; and Buick, I. S. 2005. Metamorphism and high-temperature shear zones in the Broken Hill Block, NSW, Australia. J. Metamorph. Geol. 23:745-770.

Gibson, G. M., and Nutman, A. P. 2004. Detachment faulting and bimodal magmatism in the Palaeoproterozoic Willyama Supergroup, south-central Australia: keys to recognition of a multiply deformed Precambrian metamorphic core complex. J. Geol. Soc. Lond. 161:55-66.

Gibson, G. M.; Peljo, M.; and Chamberlain, T. 2004. Evidence and timing of crustal extension versus shortening in the early tectonothermal evolution of the Proterozoic continental rift sequence at Broken Hill, Australia. Tectonics, vol. 23, TC5012.

Goodge, J. W.; Hansen, V. L.; Peacock, S. M.; Smith, B. K.; and Walker, N. W. 1993. Kinematic evolution of the Miller Range shear zone, central Transantarctic Mountains, Antarctica, and implications for Neoproterozoic to early Palaeozoic tectonics of the East Antarctic margin of Gondwana. Tectonics 12:1460-1478.

Hand, M.; Rutherford, L.; and Barovich, K. 2003. Garnet $\mathrm{Sm}-\mathrm{Nd}$ age constraints on the timing of tectonism in the southwestern Curnamona Province: implications for existing models and correlations. Geosci. Aust. Rec. 13:65-68.

Harlov, D. E.; Wirth, R.; and Föster, H.-J. 2005. An experimental study of dissolution-reprecipitation in fluorapatite: fluid infiltration and the formation of monazite. Contrib. Mineral. Petrol. 150:268-286.

Harrison, T. M., and McDougall, I. 1981. Excess ${ }^{40} \mathrm{Ar}$ in metamorphic rocks from Broken Hill, New South 
Wales: implications for ${ }^{40} \mathrm{Ar} /{ }^{39} \mathrm{Ar}$ age spectra and the thermal history of the region. Earth Planet. Sci. Lett. 55:123-149.

Hobbs, B. E.; Archibald, N. J.; Etheridge, M. A.; and Wall, V. J. 1984. Tectonic history of the Broken Hill Block, Australia. In Kröner, A., and Greiling, R., eds. Precambrian tectonics illustrated. Stuttgart, E. Schweizerbartische, p. 353-368.

Kingsbury, J. A.; Miller, C. F.; Wooden, J. L.; and Harrison, T. M. 1993. Monazite paragenesis and U-Pb systematics in rocks of the eastern Mojave Desert, California, U.S.A.: implications for thermochronometry. Chem. Geol. 110:147-167.

Lee, J. K. W.; Williams, I. S.; and Ellis, D. J. 1997. Pb, U and Th diffusion in natural zircon. Nature 390:159162.

Loosveld, R. J. H., and Etheridge, M. A. 1990. A model for low-pressure facies metamorphism during crustal thickening. J. Metamorph. Geol. 8:257-267.

Ludwig, K. R. 2000. Isoplot/Ex, version 2.4: a geological toolkit for Microsoft Excel. Berkeley, CA, Berkeley Geochronology Center Spec. Publ. 1a.

Marjoribanks, R. W.; Rutland, R. W. R.; Glen, R. A.; and Laing, W. P. 1980. The structure and tectonic evolution of the Broken Hill Region, Australia. Precambrian Res. 13:209-240.

Montel, J.-M.; Kornprobst, J.; and Vielzeuf, D. 2000. Preservation of old $\mathrm{U}-\mathrm{Th}-\mathrm{Pb}$ ages in shielded monazite: example from the Beni Bousera Hercynian kinzigites (Morocco). J. Metamorph. Geol. 18:335-342.

Noble, M. P.; Fry, K.; Betts, P. G.; Forbes, C.; and Lister, G. S. 2003. High-temperature shear zones in the Curnamona Province. Geosci. Aust. Rec. 13:120-121.

Noble, M. P., and Lister, G. S. 2001. Discovery of a kilometre-scale early extensional shear zone that deformed the Broken Hill Pb-Zn-Ag orebody, NSW, Australia. Geol. Soc. Aust. Abstr. 64:127-128.

Nutman, A. P., and Ehlers, K. 1998. Evidence for multiple Palaeoproterozoic thermal events and magmatism adjacent to the Broken Hill Pb-Zn-Ag orebody, Australia. Precambrian Res. 90:203-238.

Page, R. W., and Laing, W. P. 1992. Felsic metavolcanic rocks related to the Broken Hill $\mathrm{Pb}-\mathrm{Zn}-\mathrm{Ag}$ orebody, Australia: geology, depositional age, and timing of high-grade metamorphism. Econ. Geol. 87:2138-2168.

Page, R. W.; Stevens, B. P. J.; and Gibson, G. M. 2005. Geochronology of the sequence hosting the Broken Hill $\mathrm{Pb}-\mathrm{Zn}-\mathrm{Ag}$ orebody, Australia. Econ. Geol. Bull. Soc. Econ. Geol. 100:633-661.

Page, R. W.; Stevens, B. P. J.; Gibson, G. M.; and Conor, C. H. H. 2000. Geochronology of Willyama Supergroup rocks between Olary and Broken Hill, and comparison to Northern Australia. Aust. Geol. Surv. Organ. Rec. 10:72-75.

Parrish, R. R. 1990. U-Pb dating of monazite and its application to geological problems. Can. J. Earth Sci. 27: 1431-1450.

Powell, R., and Downes, J. 1990. Garnet porphyroblastbearing leucosomes in metapelites: mechanisms, phase diagrams, and an example from Broken Hill, Australia. In Ashworth, J. R., and Brown, M., eds.
High-temperature metamorphism and crustal anatexis. London, Unwin Hyman, pp. 105-123.

Preiss, W. V. 2000a. The Adelaide Geosyncline of South Australia and its significance in Neoproterozoic continental reconstruction. Precambrian Res. 100:21-63.

- 2000b. Overview of the Curnamona Province and its tectonic setting. Aust. Geol. Surv. Organ. Rec. 10: 79-81.

Raetz, M.; Forbes, C.; and Lister, G. S. 2002a. Stratigraphic omission explained by discovery of a regional folded ductile shear zone in the Euriowie Block, NSW. Geol. Soc. Aust. Abstr. 67:185.

Raetz, M.; Krabbendam, M.; and Donaghy, A. G. $2002 b$. Compilation of U-Pb zircon data from the Willyama Supergroup, Broken Hill region, Australia: evidence for three tectonostratigraphic successions and four magmatic events? Aust. J. Earth Sci. 49:965-983.

Rutherford, L.; Hand, M.; and Mawby, J. 2006. Delamerian-aged metamorphism in the southern Curnamona Province, Australia: implications for the evolution of the Mesoproterozoic Olarian Orogeny. Terra Nova 18: $138-146$.

Shaw, C. A.; Karlstrom, K. E.; Williams, M. L.; Jercinovic, M. J.; and McCoy, A. M. 2001. Electron-microprobe monazite dating of ca. 1.71-1.63 Ga and ca. 1.45-1.38 $\mathrm{Ga}$ deformation in the Homestake shear zone, Colorado: origin and early evolution of a persistent intracontinental tectonic zone. Geology 29:739-742.

Stevens, B. P. J. 2000. Evaluating models for tectonic development of the Willyama Supergroup. Aust. Geol. Surv. Organ. Rec. 10:87-90.

Stevens, B. P. J.; Barnes, R. G.; Brown, R. E.; Stroud, W. J.; and Willis, I. L. 1988. The Willyama Supergroup in the Broken Hill and Euriowie Blocks, New South Wales. Precambrian Res. 40/41:297-327.

Teale, G. S., and Fanning, C. M. 2000. The timing of CuAu mineralisation in the Curnamona Province. Aust. Geol. Surv. Organ. Rec. 10:98-100.

Teufel, S., and Heinrich, W. 1997. Partial resetting of the $\mathrm{U}-\mathrm{Pb}$ isotope system in monazite through hydrothermal experiments: an SEM and U-Pb isotope study. Chem. Geol. 137:273-281.

Tonelli, M.; Woodhead, J.; and Hergt, J. 2002. Pb-Pb stepwise leaching (PbSL): a new geochronological tool for high-grade polymetamorphic terranes. Geol. Soc. Aust. Abstr. 67:300.

Venn, C. J. 2001. The geodynamic evolution of the Mount Robe and Mount Franks region, Broken Hill Australia: discovery of crustal-scale extensional shear zones and giant sheath folds. PhD thesis, Monash University, Melbourne.

Walters, S. J. 1996. An overview of Broken Hill type deposits. In Pongratz, J., and Davidson, G. J., eds. New developments in Broken Hill type deposits. CODES Spec. Publ. 1, pp. 1-10.

Williams, M. L.; Jercinovic, M. J.; and Terry, M. P. 1999. Age mapping and dating of monazite on the electron microprobe: deconvoluting multistage tectonic histories. Geology 27:1023-1026.

Willis, I. L.; Brown, R. E.; Ströud, W. J.; and Stevens, B. 
P. J. 1983. The Early Proterozoic Willyama Supergroup: stratigraphic subdivision and interpretation of high- to low-grade metamorphic rocks in the Broken Hill Block, New South Wales. J. Geol. Soc. Aust. 30: $195-224$
Zhu, X. K., and O'Nions, R. K. 1999. Zonation of monazite in metamorphic rocks and its implications for high-temperature thermochronology: a case study from the Lewisian terrain. Earth Planet. Sci. Lett. 171: 209-220. 